\title{
Spatial distribution and diet of Cephalopholis fulva (Ephinephelidae) at Trindade Island, Brazil
}

\author{
Flavio do Nascimento Coelho, Hudson Tercio Pinheiro, Robson Guimarães dos Santos, \\ Cristiano Queiroz de Albuquerque and Agnaldo Silva Martins
}

In this study we analyze the population structure and diet of the coney Cephalopholis fulva at Trindade Island, Brazil, through direct observation with SCUBA diving in 11 reef sites around the Island, up to $50 \mathrm{~m}$ deep. Diet was based on 77 individuals collected with speargun. Mean population density and biomass were estimated at 29 individuals $/ 100 \mathrm{~m}^{2}$ and $13 \mathrm{~kg} / 100 \mathrm{~m}^{2}$, respectively. This species is regularly distributed along the costal environments of the Trindade Island, with no significant differences in densities and biomass detected among the different collection habitats (reef crest, reef slope, and reef plateau). However, significantly higher densities were observed micro-habitats with greater structural complexity, which may offer more shelter and food to C. fulva. Four food item groups were identified from the gut contents of C. fulva: Annelida, Crustacea, Teleostei, and Testudinata. It is the first record of predation of the green turtle Chelonia mydas hatchlings by the coney. Trindade Island seems to present the densest concentration of $C$. fulva in all Brazilian and Caribbean ecosystems inhabited by this species. Scarcity of competitors, predators, and fishing pressure may explain the high densities observed in the Island.

Foram analisadas a estrutura populacional e a dieta do catuá Cephalopholis fulva na Ilha da Trindade, Brasil. Os dados foram obtidos através de censos visuais com mergulho autônomo em 11 locais no entorno da ilha, em profundidades de até $50 \mathrm{~m}$. A dieta e a proporção sexual foram baseadas na análise de 77 indivíduos coletados com arpão. A densidade populacional e biomassa foram estimados em 29 indivíduos $/ \mathrm{m}^{2}$ e $13 \mathrm{~kg} / 100 \mathrm{~m}^{2}$, respectivamente. A espécie apresentou distribuição uniforme nos ambientes costeiros da ilha, não tendo sido registradas diferenças significativa em sua densidade e biomassa entre os diferentes habitats estudados (crista, talude e platô recifal). Entretanto, foi observado preferência por micro-habitats de alta complexidade estrutural. Foram registrados quatro grupos de itens alimentares no conteúdo estomacal de C. fulva: Annelida, Crustacea, Teleostei e Testudinata. É feito aqui o primeiro registro de predação de juvenis da tartaruga-verde (Chelonia mydas) por C. fulva. Trindade parece apresentar os maiores valores de densidade para o catuá, quando comparada a outras localidades do Brasil e Caribe. A escassez de competidores, predadores e a pressão pesqueira são possíveis fatores que podem explicar as altas densidades observadas para C. fulva na Ilha da Trindade.

Key words: Chelonia mydas, Coney, Feeding ecology, Grouper, Oceanic islands, Reef fish.

\section{Introduction}

The distribution of fish species along a reef ecosystem is believed to be ruled by abiotic (e.g. depth, water quality, substrate type) and biotic (e.g. recruitment, predation, competition) factors (Sale, 1991; Bellwood \& Wainwright, 2002; Mendonça-Neto et al., 2008). Habitat type and substrate structural complexity have been suggested to be important environmental traits structuring reef fish populations (Ferreira et al., 2001; Fox \& Bellwood, 2007). These environmental traits are expected to influence fish distribution by offering structures as rocks and holes where fish can hide from predators and look for food under relatively safe conditions (Willis \& Anderson, 2003; Overholtzer-McLeod, 2004). Food availability has also been reported to be an important factor structuring the reef fish distribution (Nagelkerken et al., 2001; Beukers-Stewart \& Jones, 2004; Floeter et al., 2007). Considering habitat preferences and food availability, the site inhabited by a given fish species is presumibly selected in response to the optimization of net energy gain and avoidance of predators and competitors (Baltz \& Jones, 2003). Trindade is the most isolated Brazilian island, located at 1,160 km from the Brazilian central coast in the eastern end of the Vitória-Trindade submarine ridge (Fig. 1). The island presents an emerged area of about $9.3 \mathrm{~km}^{2}$ which is surrounded by a narrow shelf of 32 $\mathrm{km}^{2}$ (0-50 m deep) mostly covered by fringing and rock reefs, and few species of corals, zoanthids, and sponges (Gasparini \& Floeter, 2001; Pereira-Filho et al., 2011). These reef environments comprise areas with diverse structural complexity regarding the presence and size of holes and rocks representing

Universidade Federal do Espírito Santo, Departamento de Oceanografia e Ecologia, Av. Fernando Ferrari, 514, Goiabeiras, 29075-910 Vitória, ES, Brazil. coelhofn@hotmail.com 
optimal habitats for fish. Despite this island has been declared an ecological reserve, fishing is still allowed, and pelagic longline, trolling bottom line and handline have been reported around the island (Pinheiro et al., 2010). Moreover, signs of top predators overfishing have been recently observed (Pinheiro et al., 2010, 2011; Pereira-Filho et al., 2011).

The coney, Cephalopholis fulva (Linnaeus, 1758), stands out since its abundance easily overcome all the other predator fish species in Trindade island (Pinheiro et al., 2011). It is a relatively medium-sized fish (maximum length of $40 \mathrm{~cm}$ ) from the Epinephelidae family that usually inhabits reef areas in tropical environments of the Western Atlantic Ocean (Heemstra \& Randall, 1993). In other Brazilian waters, C. fulva is an abundant carnivore commonly found in coastal reefs, embankments and the oceanic islands of Fernando de Noronha and Atol das Rocas (Ferreira et al., 2004; Fredou et al., 2006; Martins et al., 2007; Krajewski \& Floeter, 2011). Described as a piscivorous and invertivorous fish (Randall, 1967; Heemstra \& Randall, 1993; Lieske \& Myers, 1994), C. fulva is believed to play an important role as a predator in reef habitats and adjacent areas in which it is capable of influencing the abundance of many available preys (Webster, 2003; Overholtzer-McLeod, 2004; White, 2007). This species represents an important fishery resource in the Caribbean Sea (Heemstra \& Randall, 1993), and it has been extensively exploited in the Brazilian central coast (Klipel et al., 2005). Despite its ecological and commercial importance, there are only few studies focusing specifically on the population dynamics of $C$. fulva in Brazil (Araújo \& Martins, 2006, 2009; Freitas et al., 2011). Due to its high abundance in Trindade Island (Pereira-Filho et al., 2011; Pinheiro et al., 2011) ,C. fulva stands out as a model organism to evaluate ecological issues such as diet and habitat preferences. In this study, the relationship between diet and distribution of C. fulva at coastal reef areas of Trindade island, was evaluated, focusing particularly on its preferences for different habitat types and microhabitats with varying levels of structural complexity.

\section{Material and Methods}

The population structure of C. fulva was evaluated using underwater visual censuses $(\mathrm{UVC} ; \mathrm{n}=144)$ carried out between April-June 2009 at 11 sites around the coast of Trindade Island (Fig. 1) during day light (9:00 to 16:00 h). Samples were composed by $20 \times 2 \mathrm{~m}$ transects. The transect width was chosen to allow comparisons with other previously reported studies on the Brasilian coast (Ferreira \& Gonçalves, 2006; Floeter et al., 2007; Mendonça-Neto et al., 2008).

Each site was separated into three major microhabitats where fish censuses were performed (Fig. 2). (1) The reef crest is located at the surf zone, with depths of about 3-6 m; (2) the reef slope, with depths varying between 6-20 m; and (3) the reef plate, the deepest habitat sampled, with depths $>20 \mathrm{~m}$ and limited in the deepest portion by non-consolidated substrata. Structural complexity was assessed visually by classifying the substrate rugosity according the following three categories: high complexity (rocks and holes $>1 \mathrm{~m}$ in length and depth), medium complexity (rocks and holes $<$ $1 \mathrm{~m}$ ), low complexity (lack of rocks and holes) (Floeter et al., 2007; Pinheiro et al., 2011; Simon et al., 2011).

During UVC sampling, fish individuals were included in five length classes $(0-5,5-10,10-20,20-30$, and 30-40 cm). Biomass was estimated using length through the weightlength relationships (Froese \& Pauly, 2010). Mean density and biomass of C. fulva from the three coastal habitats and substrate-complexity levels were compared with the KruskalWhallis test since these data did not follow normal distribution.

Diet was characterized using data from the Tartaruga's reef(Fig. 1). This reef was selected because it is representative

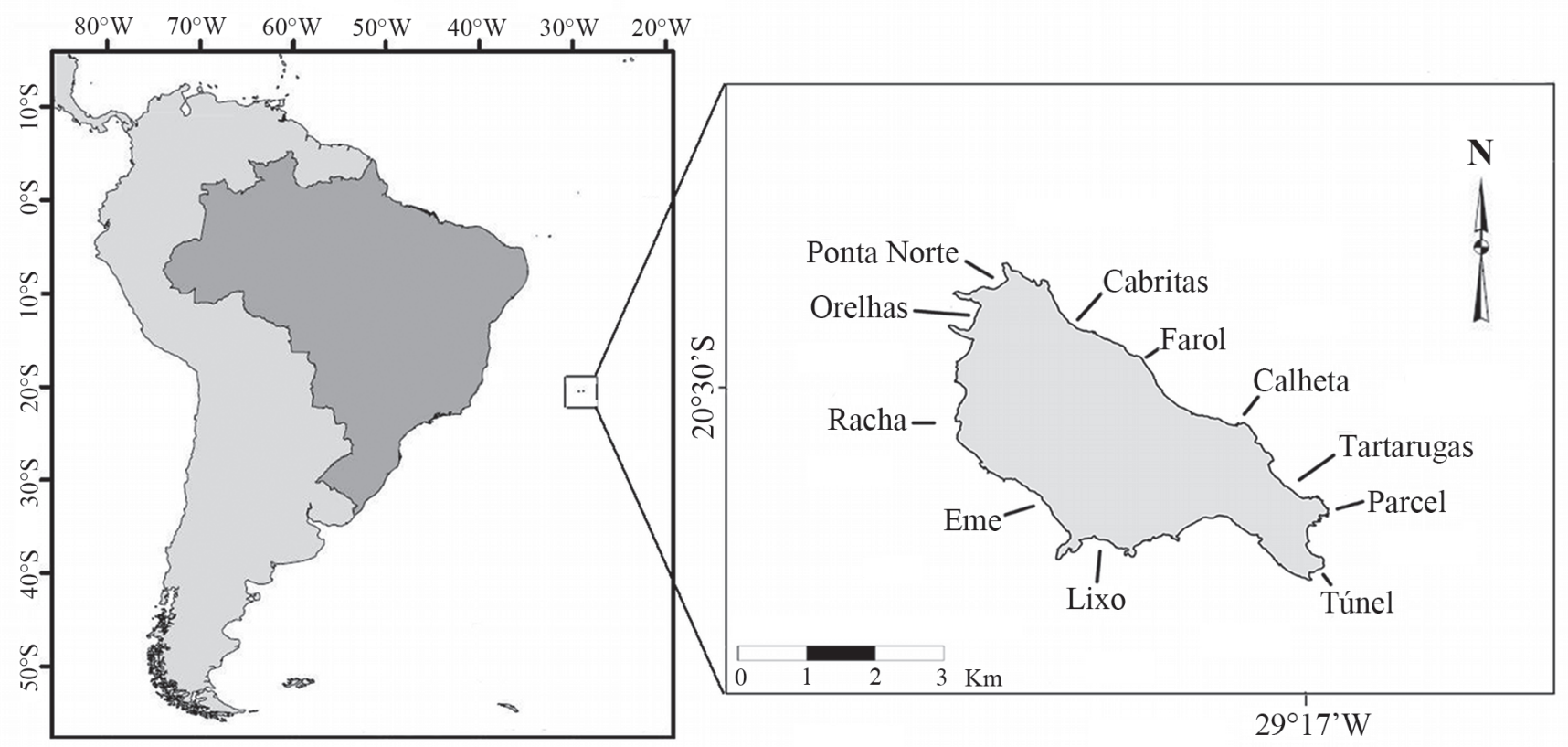

Fig. 1. Map of Trindade Island, off the Brazilian Central Coast, indicating the sampled sites. 
Fringing Reefs
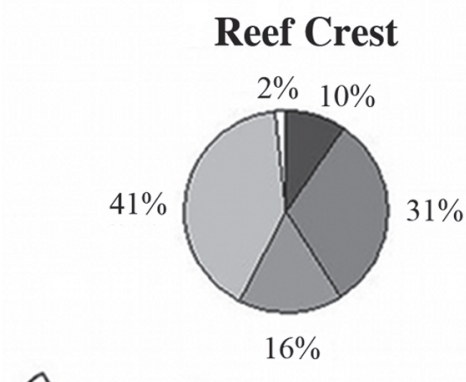

Benthic Community

- Sponge

$\square$ Macroalgae

$\square$ Crustose coralline algae

$\square$ Turf Algae

$\square$ Sand/rubble

\section{Reef Slope}

$12 \% \quad 7 \%$

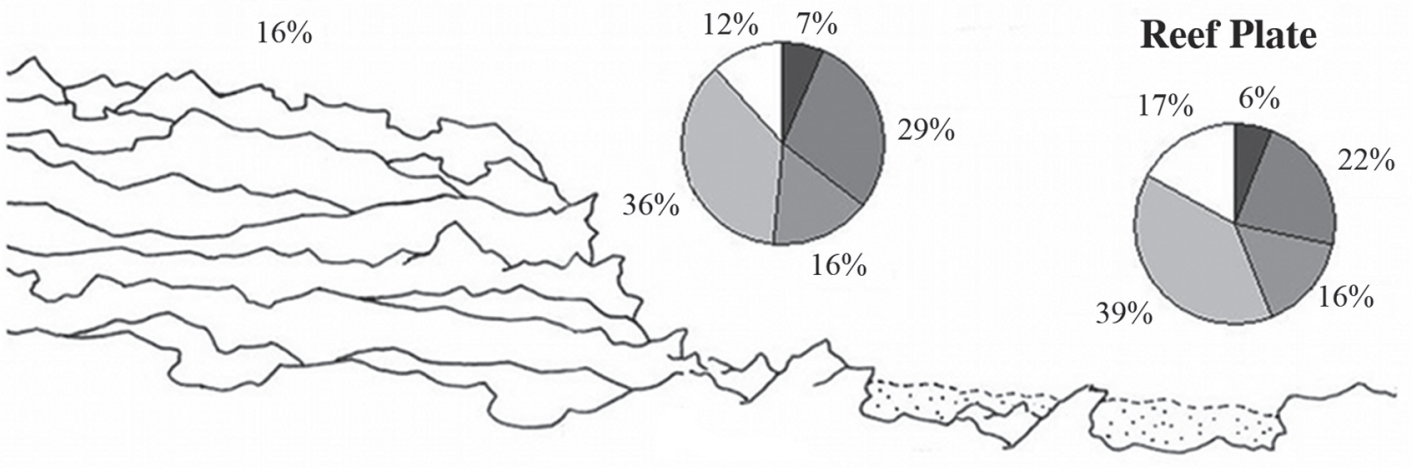

Structural Complexity of Substrata

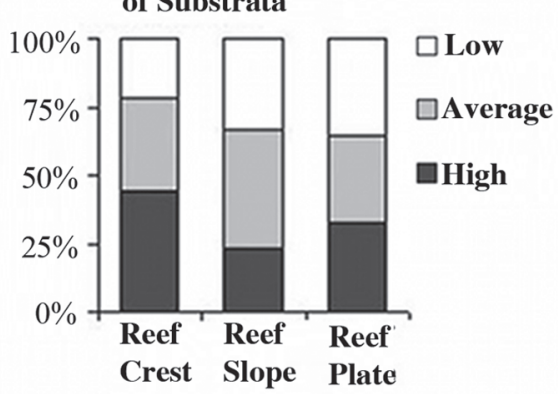

Fig. 2. Diagram showing profiles of fringing reefs of Trindade Island, Brazil. Benthic cover and substrate structural complexity of each habitat are presented.

of the main common reef environment across the island, and due to logistical aspects. Biological samples were collected from the reef crest, reef slope, and reef plate. A total of 77 individuals of C. fulva were collected using speargun. These fish where eviscerated and stomachs were preserved in ethanol $70 \%$. Food items were identified to the lowest possible taxonomic level, counted and weighed. Diet composition was evaluated according to Pinkas et al. (1971), where the importance of each type of prey was assessed through its relative frequency of occurrence $(\% \mathrm{~F})$, relative numerical frequency $(\% \mathrm{~N})$, percentage of wet weight $(\% \mathrm{~W})$ and the Index of Relative Importance [(IRI $=\% \mathrm{~F}(\% \mathrm{~N}+\% \mathrm{~W})]$, expressed in percentage as suggested by Cortés (1997). Differences in diet between reef habitats regarding those major taxa were evaluated through Analysis of Similarity (ANOSIM). The data was square-root transformed and the similarity matrices were calculated using the Bray-Curtis index.

\section{Results}

The coney population at Trindade Island presented an overall mean abundance of 29 individuals $/ 100 \mathrm{~m}^{2}$ and biomass of $13 \mathrm{~kg} / 100 \mathrm{~m}^{2}$. Density values were highest for the $20-30 \mathrm{~cm}$ size class, while highest biomass values were recorded for the $30-40 \mathrm{~cm}$ size class (Fig. 3). The coney presented a broad distribution across the coastal habitats of the island, with no significant differences in density and biomass between the three reef habitats (KW; $>>0.05$ ). However, abundance of $C$. fulva varied significantly according to substrate complexity, with greater values recorded to microhabitats with higher structural complexity (KW; $<<0.001$, Fig. 5).

From the 77 stomachs analyzed, 63 (81.8\%) contained food. Food items were classified into nine categories (1 Polychaeta, 5 Crustacea, 2 Teleostei, 1 Testudinata) and two categories related to fragmented items of Crustacea and Teleostei (Table 1). The most important items (IRI) in decreasing order were: Testudinata (37\%), Teleostei (32\%), and Crustacea (30.3\%). The most frequent items (FO \%) were: Crustacea (69.4\%) and Teleostei (41\%). Numerically, the most important items were Crustacea (53\%) and Teleostei (31\%). Testudinata stood out in respect to weight, representing $81 \%$ of total weight found in the stomachs (Fig. 5) and about $9 \%$ of the total number of analyzed stomachs. Diet of the coney did not differ significantly between the three reef habitats when considering frequency of items (ANOSIM, Global $\mathrm{R}=0.006, \mathrm{p}>0.05$ ) nor items weight (ANOSIM, Global R=0.006, $\mathrm{p}>0.05)$.

\section{Discussion}

The coney population from Trindade Island was much more dense than the average range of densities about 0.15 to 12 individuals $/ 100 \mathrm{~m}^{2}$ reported for Brazilian waters (Floeter et al., 2007; Krajewski \& Floeter, 2011) and from 0.1 to 19 individuals/ $100 \mathrm{~m}^{2}$ reported for the Caribbean (Chiappone et al., 2000; White, 2007). Recent studies on C. fulva in Trindade Island found population densities from about 10 individuals $/ 100 \mathrm{~m}^{2}$ (Pereira- 

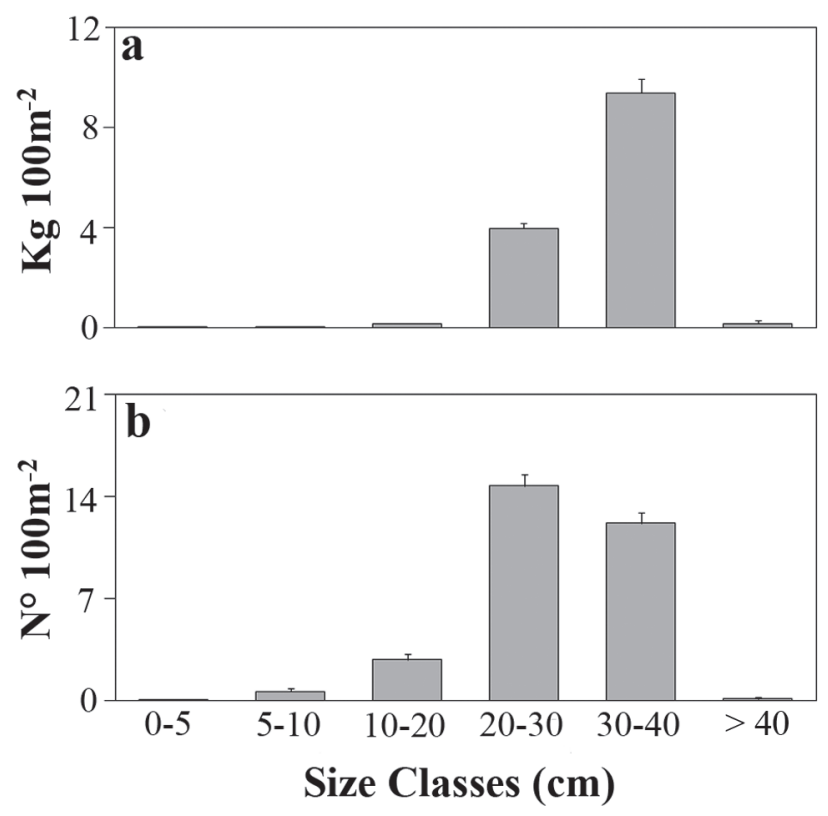

Fig. 3. Biomass (a) and Abundance (b) of different size classes of C. fulva at Trindade Island, Brazil. The error bars indicate standard error (SE).

Filho, 2011) and suggested Trindade waters may be already subject to overfishing due the lack of large predators. Some other studies in Brazilian waters have reported that C. fulva is usually associated with tropical reefs and its relative frequencies are usually lower than $1 \%$ of all observed fish species in these environments (Ferreira et al., 2004; Francini-Filho \& Moura, 2008). The high densities observed in our study may be explained by some factors, such as: firstly, Brazilian oceanic islands usually show lower diversity of small carnivores than that observed in coastal reef environments (Ferreira et al., 2004). Thus, it is possible that $C$. fulva faces less competition with other carnivorous organisms in oceanic islands than in coastal areas, which could partially explain the high population density recorded here. The second factor would be the geographic isolation of the Island. Since Trindade Island is reasonably far from the continent, environmental issues as pollution, introduction of non-indigenous species and habitat loss are expected to be less intense than they are for more coastal areas and islands. In fact, the coney has been shown to be more abundant in oceanic banks and islands (Atol das Rocas, Fernando de Noronha and Trindade Island) than in the continental coastal regions (Floeter et al., 2007; Krajewski \& Floeter, 2011; Pinheiro et al., 2011). Thirdly, fisheries at Trindade Island are mostly focused on larger fish species such as Carcharhinus perezii, Xiphias gladius, Mycteroperca venenosa, Ephinephelus adscensionis (Pinheiro et al., 2010), which may also contribute to reduced competition and predation over C. fulva. It has been shown that in highly fished waters of the Caribbean, small non-targeted species such as C. fulva and C. cruentatus have become locally dominant (Chiappone et al., 2000; Stallings, 2008; Mumby et al., 2012). Therefore, we suggest
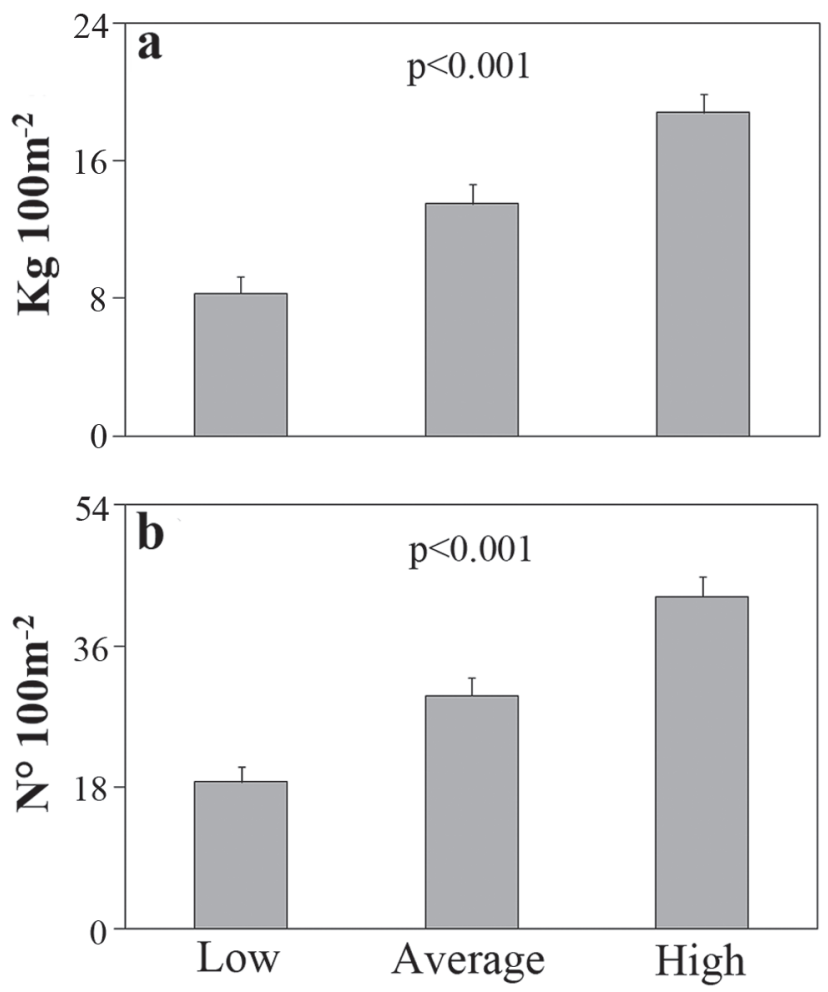

Fig. 4. Biomass (a) and Abundance (b) of C. fulva according to structural complexity of reef substrate at Trindade Island, Brazil. Error bars indicate standard error (SE).

the local fishery may be an important factor acting towards the increase of $C$. fulva's density in Trindade Island.

In this study we have also observed that C. fulva was more abundant in more complex habitats. Environmental structural complexity has been reported as one of the main ecological attributes capable of influencing the community structure of reef fishes (Bell \& Galzin, 1984; Ferreira et al., 2001). In reef habitats, the fish's choice for a place to live takes in account a trade off between the competition intensity, food availability and risk of predation (Shpigel \& Fishelson, 1991; Overholtzer-McLeod, 2004; Gibran, 2007). High densities of refuge-seeking invertebrates have been suggested to inhabit highly complex substrates (Webster \& Hat, 2004), therefore, aggregations of small and medium-sized predators over these microhabitats may be related to their feeding strategy, as previously reported (Willis \& Anderson, 2003; Almany, 2004; White, 2007). However, the diet of C. fulva was similar between different habitats, which allow suggesting that food availability is not likely to be an important factor explaining C. fulva's habitat preferences. Unfortunately, our data do not allow evaluating the effectiveness of competition for food nor space with other fish species as a source of population structuring. Undoubtedly, highly complex substrates provide more protection against predators and may be an important factor inducting the increase of $C$. fulva abundance in such areas.

In addition to presenting the diet of this species for the first time in South-western Atlantic waters, we show evidence that 


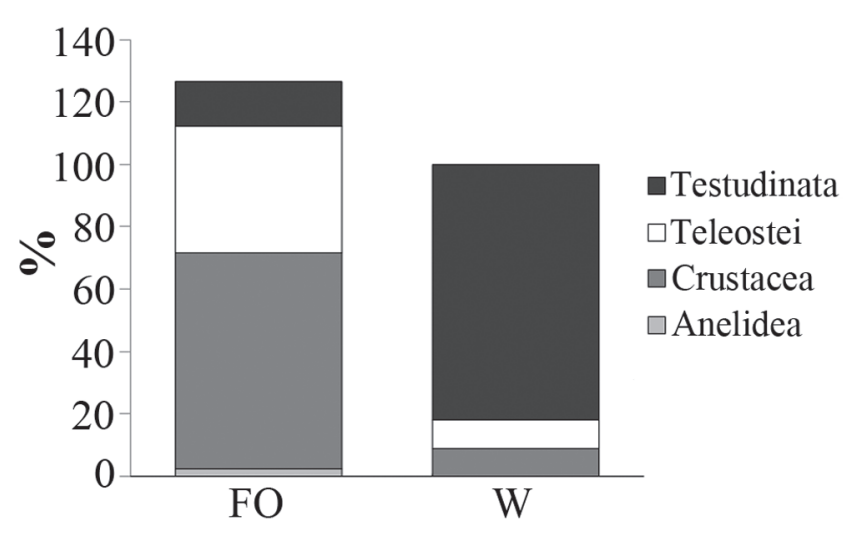

Fig. 5. Frequency of occurrence ( $\% \mathrm{FO})$ and weight $(\% \mathrm{~W})$ of food items present in C. fulva's gut content at Trindade Island, Brazil.

reinforce the coney as an opportunistic predator. We have observed predation on seasonal resources as green turtle (Chelonia mydas) hatchlings, which represents the first record of this type of prey for C. fulva. Trindade Island, where a large amount of offspring hatch during four months every year (Moreira et al., 1995), is the third largest reproductive site of $C$. mydas in the Atlantic ocean (Seminoff, 2002). Sea turtle hatchlings are known as a seasonal resource of high energy value for many opportunistic predators (Bouchard \& Bjorndal, 2000). Considering the high abundance of C. fulva and that $9 \%$ of the sampled individuals were found to feed on green turtles, their estimated predation pressure on green turtles could be reasonably high around the shallow habitats of Trindade Island. In fact, C. fulva is an opportunistic predator that uses different foraging tactics (Sazima et al., 2005).

Considering the ecological traits of $C$. fulva such as high abundance, wide spatial distribution and opportunist feeding habits, we suggest that this species play an important role in

Table 1. Frequency of occurrence ( $\% \mathrm{FO})$, numerical frequency $(\% \mathrm{FN})$, percentage of wet weight $(\% \mathrm{~W})$ and percentage of relative importance index of food items on gut contents of $C$. fulva at Trindade Island, Brazil. Bold prints indicate totals.

\begin{tabular}{lcccc}
\hline Items & $\% \mathrm{FO}$ & $\% \mathrm{FN}$ & $\% \mathrm{~W}$ & $\% \mathrm{IRI}$ \\
\hline Annelida & $\mathbf{2 . 0}$ & $\mathbf{1 . 6}$ & $\mathbf{0 . 1}$ & $\mathbf{0 . 1}$ \\
$\quad$ Polychaeta & 2.0 & 1.6 & 0.1 & 0.1 \\
Crustacea & $\mathbf{6 9 . 4}$ & $\mathbf{5 3 . 3}$ & $\mathbf{8 . 3}$ & $\mathbf{3 0 . 3}$ \\
Caridea & 8.2 & 6.3 & 1.1 & 1.7 \\
$\quad$ Brachyura & 2.0 & 1.6 & 0.1 & 0.1 \\
Percnon gibbesi & 24.5 & 18.8 & 3.1 & 15.1 \\
Stomatopod & 14.3 & 10.9 & 2.8 & 5.5 \\
Palinura & 2.0 & 1.6 & 0.1 & 0.1 \\
Crustacean fragments & 18.4 & 14.1 & 1.1 & 7.8 \\
Teleostei & $\mathbf{4 4 . 7}$ & $\mathbf{3 4 . 4}$ & $\mathbf{1 0 . 5}$ & $\mathbf{3 2 . 5}$ \\
$\quad$ Ophioblennuis sp & 2.0 & 1.6 & 0.2 & 0.1 \\
$\quad$ Thalassoma noranhanum & 6.1 & 4.7 & 0.3 & 0.9 \\
$\quad$ Teleostei fragments & 36.6 & 28.1 & 10.0 & 31.5 \\
Testudinata & $\mathbf{1 4 . 3}$ & $\mathbf{1 0 . 9}$ & $\mathbf{8 1 . 2}$ & $\mathbf{3 7 . 1}$ \\
$\quad$ Chelonia mydas & 14.3 & 10.9 & 81.2 & 37.1 \\
\hline
\end{tabular}

the reef trophic dynamics of Trindade Island. In oceanic environments, the coney is capable of feeding on many preyspecies, particularly the ones that show high abundance at some periods of the year, as we observed for the green turtle hatchlings. Therefore, C. fulva is likely to control the abundance of its preys, thus possibly improving the equilibrium and resilience of the reef environments of Trindade Island.

\section{Acknowledgements}

The authors would like to thank Karla Gonçalves da Costa who helped with the invertebrate identification. We thank also Projeto Tamar, Brazilian Navy, WinDive, Flamar, Voz da Natureza and the team of Lab. Necton - UFES. F. N. C. and H. T. P. received respectively a FACITEC and CAPES-PPGOAM scholarships. C. Q.A. was supported by CAPES/PNPD- 02907/09-7.Additionally, we thank CNPq (Conselho Nacional de Desenvolvimento Científico e Tecnológico) that funded A.S.M. (308867/2006-8).

\section{Literature Cited}

Almany, G. R. 2004. Does increased habitat complexity reduce predation and competition in coral reef fish assemblages? Oikos, 106: 275-284.

Araújo, J. N. \& A. S. Martins. 2006. Age and growth of coney (Cephalopholis fulva), from the central coast of Brazil. Journal of the Marine Biological Association of the United Kingdom, 86: 187-191.

Araújo, J. N. \& A. S. Martins. 2009. Aspects of the population biology of Cephalopholis fulva from the central coast of Brazil. Journal of Applied Ichthyology, 25: 328-334.

Baltz, D. M. \& R. F. Jones. 2003. Temporal and spatial patterns of microhabitat use by fishes and decapod crustaceans in a Louisiana estuary. Transactions of the American Fisheries Society, 132: 662-678.

Bell, J. D. \& R. Galzin. 1984. Influence of live coral cover on coral-reef fish communities. Marine Ecology Progress Series, 15: 265-274.

Bellwood, D. R. \& P. C. Wainwright. 2002. The history and biogeography of fishes on coral reefs. Pp. 5-32. In: P. F. Sale (Ed.) Coral reef fishes: dynamics and diversity on a complex ecosystem. San Diego, Academic Press, 443p.

Beukers-Stewart, B. D. \& G. P. Jones. 2004. The influence of prey abundance on the feeding ecology of two piscivorous species of coral reef fish. Journal of Experimental Marine Biology and Ecology, 299: 155-184.

Bouchard, S. S. \& K. A. Bjorndal. 2000. Sea turtles as biological transporters of nutrients and energy from marine to terrestrial ecosystems. Ecology, 81: 2305-2313.

Chiappone, M., R. Sluka \& K. S. Sealey. 2000. Groupers (Pisces: Serranidae) in fished and protected areas of the Florida Keys, Bahamas and northern Caribbean. Marine Ecology Progress Series, 198: 261-272.

Cortés, E. 1997. A critical review of methods of studying fish feeding based on analysis of stomach contens: application to elasmobranch fishes. Canadian Journal of Fisheries and Aquatic Sciences, 54: 726-738.

Ferreira, C. E. L., S. R. Floeter, J. L. Gasparini, B. P. Ferreira \& J. C. Joyeux. 2004. Trophic structure patterns of Brazilian reef fishes: a latitudinal comparison. Journal of Biogeography, 31: 1093-1106. 
Ferreira, C. E. L. \& J. E. A. Gonçalves. 2006. Community structure and diet of roving herbivorous reef shes in the Abrolhos Archipelago, south-western Atlantic. Journal of Fish Biology, 69: 1533-1551.

Ferreira, C. E. L., J. E. A. Gonçalves \& R. Coutinho. 2001. Community structure of fishes and habitat complexity on a tropical rocky shore. Environmental Biology of Fishes, 61: 353-369.

Floeter, S. R., W. Krohling, J. L. Gasparini, R. L. C. Ferreira \& I. R. Zalmon. 2007. Reef fish community structure on coastal islands of the southeastern Brazil: the influence of exposure and benthic cover. Environmental Biology of Fishes, 78: 147-160.

Fox, R. J. \& D. R. Bellwood. 2007. Quantifying herbivory across a coral reef depth gradient. Marine Ecology Progress Series, 339: 49-59.

Francini-Filho, R. B. \& R. L. Moura. 2008. Dynamics of fish assemblages on coral reefs subjected to dierent management regimes in the Abrolhos Bank, eastern Brazil. Aquatic conservation: Marine and Freshwater Ecossystems, 18: 1166-1179.

Fredou, T., B. P. Ferreira \& Y. Letourneur. 2006. A univariate and multivariate study of reef fisheries of Northeastern Brazil. Journal of Marine Science, 63: 883-896.

Freitas, M. O., R. L. Moura, R. B. Francini-Filho \& C. V. MinteVera. 2011. Spawning patterns of commercially important reef fish (Lutjanidae and Serranidae) in the tropical western South Atlantic. Scientia Marina, 75: 135-146.

Froese, R. \& D. Pauly. 2010. FishBase. World Wide Web electronic publication. www.fishbase.org, version (07/2010)

Gasparini, J. L. \& S. R. Floeter. 2001. The shore fishes of Trindade Island, western South Atlantic Journal of Natural History, 35: 1639-1656.

Gibran, F. Z. 2007. Activity, habitat use, feeding behavior, and diet of four sympatric species of Serranidae (Actinopterygii: Perciformes) in southeastern Brazil Neotropical Ichthyology, 5: 387-398.

Heemstra, P. C. \& J. E. Randall. 1993. FAO Species Catalogue. Groupers of the World (Family Serranidae, Subfamily Epinephelinae): An annotated and illustrated catalogue of the grouper, rockod, hind, coral grouper and lyretail species know to date. FAO Fisheries Synopsis, Rome, 382p.

Klipel, S., A. S. Martins, G. Olavo, P. A. S. Costa \& M. B. Peres. 2005. Estimativas de desembarque da pesca de linha na costa central do Brasil (estados do Espírito Santo e Bahia) para um ano padrão (1997-2000). Pp. 71-82. In: Costa, P. A. S., A. S. Martins \& G. Olavo (Eds.). Pesca e potenciais de exploração de recursos vivos na região central da Zona Econômica Exclusiva brasileira. Rio de Janeiro, Museu Nacional, 247p.

Krajewski, J. P. \& S. R. Floeter. 2011. Reef fish community structure of the Fernando de Noronha Archipelago (Equatorial Western Atlantic): the influence of exposure and benthic composition. Environmental Biology of Fishes, 92: 25-40.

Lieske, E. \& R. Myers. 1994. Coral reef fishes. Indo-Pacific \& Caribbean including the Red Sea. Haper Collins Publishers, Glasgow, 400p.

Martins, A. S., G. Olavo \& P. A. S. Costa. 2007. Padrões de distribuição e estrutura de comunidades de grandes peixes recifais na costa central do Brasil. Pp. 45-61. In: Costa, P. A. S., G. Olavo \& A. S. Martins (Eds.). Biodiversidade da fauna marinha profunda na costa central brasileira. Rio de Janeiro, Museu Nacional, 184p.

Mendonça-Neto, J. P., C. Monteiro-Neto \& L. E. Moraes. 2008. Reef fish community structure on three islands of Itaipu, Southern Brasil. Neotropical Ichthyology, 6: 267-274.

Moreira, L., C. Baptistotte, J. Scalfone \& C. J. Thomé. 1995. Occurrence of Chelonia mydas on the Island of Trindade, Brazil. Marine Turtle News letter, 70: 2-2.
Mumby, P. J., R. S. Steneck, A. J. Edwards, R. Ferrari, R. Coleman, A. R. Harborne \& J. P. Gibson. 2012. Fishing down a Caribbean food web relaxes trophic cascades. Marine Ecology Progress Series, 445: 13-24.

Nagelkerken, I., G. van der Velde \& E. Cocheret de la Morinière. 2001. Fish feeding guilds along a gradient of bay biotopes and coral reef depth zones. Aquatic Ecology 35: 73-86.

Overholtzer-McLeod, K. L. 2004. Variance in reef spatial structure masks density dependence in Coral-Reef fish populations on natural versus artificial reefs. Marine Ecology Progress Series, 276: 269-280.

Pereira-Filho, G. H., G. M. Amado-Filho, S. M. P. B. Guimarães, R. L. Moura, P. Y. G. Sumida, D. P. Abrantes, R. G. Bahia, A. Z. Arthur Z. Guth, R. R. Jorge \& R. B. Francini Filho. 2011. Reef fish and benthic assemblages of the Trindade and Martin Vaz island group, southwestern atlantic. Brazilian Journal of Oceanography, 59: 201-212.

Pinheiro, H. T., C. E. L. Ferreira, J. C. Joyeux, R. G. Santos \& P. A. Horta. 2011. Reef fish structure and distribution in a southwestern Atlantic Ocean tropical island. Journal Fish Biology, 79: 1984-2006.

Pinheiro, H. T., A. S. Martins \& J. L. Gasparini. 2010. Impact of commercial fishing on Trindade island and Martin Vaz archipelago, Brazil: Characteristics, conservation status of the species involved and prospects for preservation. Brazilian Arquives of Biology and Technology, 53: 1417-1423.

Pinkas, L. M., S. Oliphant \& I. L. K. Iverson. 1971. Food habits of albacore, bluefin tuna and bonito in Californian waters. Californian Fish Game, 125: 1-105.

Randall, J. E. 1967. Food habits of reef fishes of the West Indies. 5: 665-847.

Sale, P. F. 1991. The ecology of fishes on coral reefs, San Diego, 754p.

Sazima, I., J. P. Krajewski, R. M. Bonaldo \& C. Sazima. 2005. Wolf in a sheep's clothes: juvenile coney (Cephalopholis fulva) as an aggressive mimic of the brown chromis (Chromis multilineata). Neotropical Ichthyology, 3: 315-318.

Seminoff, J. A. 2002. 2002. IUCN red list global status assessment: green turtle (Chelonia mydas). UCN/SSC Marine Turtle Specialist Group, Gland, 93p.

Shpigel, M. \& L. Fishelson. 1991. Territoriality and Associated Behavior in 3 Species of the Genus Cephalopholis (Pisces, Serranidae) in the Gulf of Aqaba, Red-Sea. Journal of Fish Biology, 38: 887-896.

Simon, T., H. T. Pinheiro \& J. C. Joyeux. 2011. Target shes on articial reefs: Evidences of impacts over nearby natural environments. Science of the Total Environment, 409: 4579-4584.

Stallings, C. D. 2008. Indirect effects of an exploited predator on recruitment of coral-reef fishes. Ecology, 89: 2090-2095.

Webster, M. M. \& J. B. Hart. 2004. Substrate discrimination and preference in foraging fish. Animal Behaviour, 68: 1071-1077.

Webster, M. S. 2003. Temporal density dependence and population regulation in a marine fish. Ecology, 84: 623-628.

White, J. W. 2007. Spatially correlated recruitment of a marine predator and its prey shapes the large-scale pattern of densitydependent prey mortality. Ecology Letters, 10: 1054-1065.

Willis, T. J. \& M. J. Anderson. 2003. Structure of cryptic reef fish assemblages: Relationships with habitat characteristics and predator density. Marine Ecology Progress Series, 257: 209-221.

Submitted October 14, 2011 Accepted May 11, 2012 Published June 29, 2012 